\title{
Juniper removal may not increase overall Klamath River Basin water yields
}

\author{
by Timothy J. Kuhn, Kenneth W. Tate, \\ David Cao, and Melvin R. George
}

\section{Based on published research and watershed assessment techniques,} we evaluated the feasibility of augmenting water yields in the Klamath River and its major tributaries by removing western juniper, which has expanded dramatically within the Klamath River Basin over the past 130 years. The results suggest that the conversion of western juniper woodlands to shrublands or grasslands would not substantially increase water yields for the Basin as a whole. However, researchers should further examine the potential for juniper management to increase both summer flow rates in small tributaries and spring flows that support small wetlands across the upper Basin; other possible benefits could include restoring wildlife in sagebrushrangeland habitat, reducing wildfire risks and increasing the land available for livestock grazing.

Ri ecent droughts in the western United States have highlighted the overall scarcity of surface and groundwater supplies, and intensified the conflict between competing water-use demands. Regional water shortages could increase during this century, given the reduced precipitation and increased temperatures forecast by some climate change models. The Klamath River Basin (fig. 1) provides a prime example of the challenges created by an inadequate water supply, particularly in a region with multiple competing uses, such as salmon fisheries, farming, livestock production and power generation.

In 2001, for example, water shortage forecasts in the Klamath River resulted in the closure of agricultural irrigation supplies in order to maintain adequate in-stream flows for salmon runs. Levy

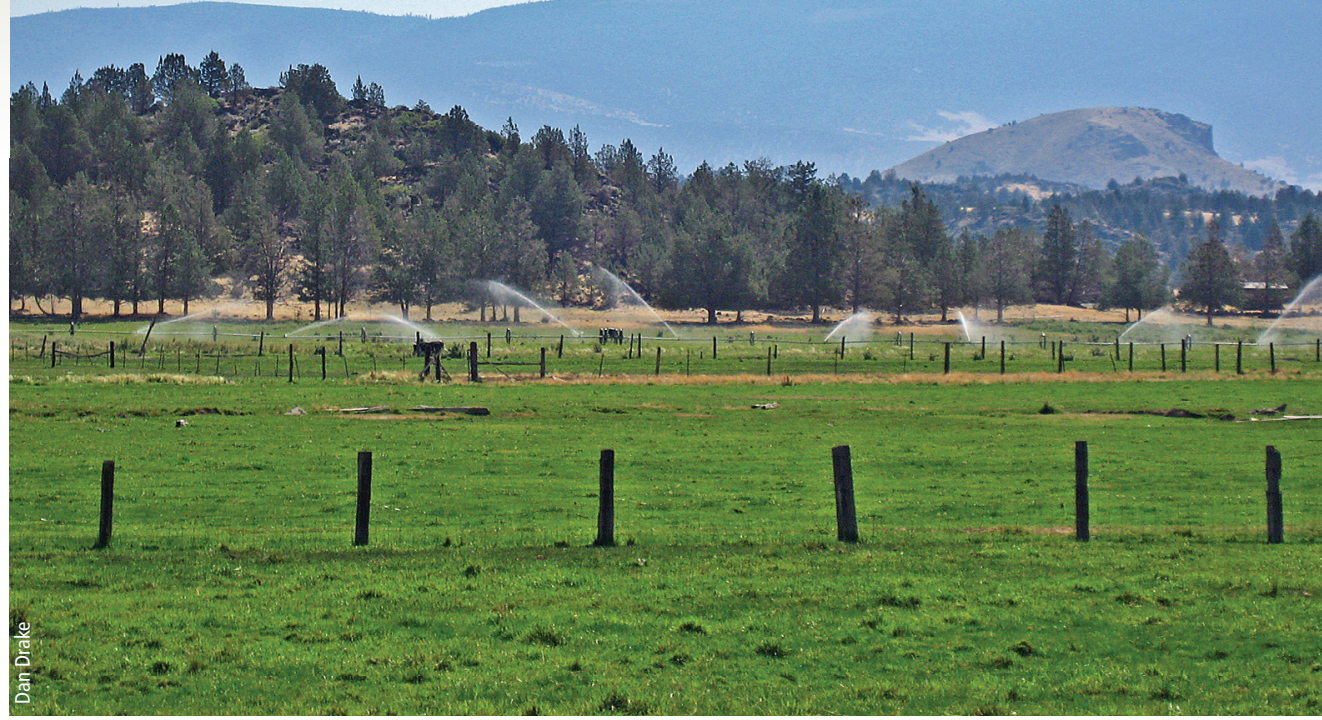

In the Klamath River Basin, water for irrigation, power, drinking and wildlife is scarce, and competition for this limited resource remains intense. In recent decades, the range of native juniper (background), a water-demanding tree, has expanded in the region due to fire suppression and land-use changes.

(2003) reported that this closure resulted in agricultural losses exceeding $\$ 200$ million. Conversely, in 2002 water was rationed to irrigation rather than to in-stream flows. This resulted in one of the worst fish kills in western U.S. history, claiming more than 30,000 salmon and steelhead in the lower Klamath River (Levy 2003). The conflict over Klamath River water continues: Recent federal advisory committee recommendations to protect fish species resulted in major cutbacks on commercial salmon fishing along 700 miles of California and Oregon coastline, significantly affecting the economies of coastal fishing communities.

\section{Western juniper control}

Stakeholders throughout the Basin are interested in watershed management alternatives to increase flow volumes in the Klamath River and its major tributaries. Some land managers are considering or have been restoring sagebrush rangelands by removing western juniper (Juniperus occidentalis) in arid tributaries of the eastern Klamath River Basin where it has become dominant due to fire suppression (figs. 1 and 2). Western juniper is a water-demanding evergreen tree that was historically restricted across north- east California and eastern Oregon by naturally occurring fires. However, fire prevention and control in the region have allowed western juniper to increase in extent and dominance over the past 130 years (Miller et al. 2005). One possible consequence of increased juniper dominance is that a greater portion of precipitation falling in these arid subbasins is used by juniper trees, resulting

\section{Glossary}

Evapotranspiration: The sum of transpiration and evaporation of water from a watershed or site.

Interception: The portion of precipitation retained by vegetation canopy or litter and lost from a watershed or site as evaporation.

Stemflow: The portion of precipitation that reaches the soil surface by flowing down the stems of trees, shrubs, forbs or grasses.

Throughfall: The portion of precipitation that reaches the soil surface by passing through, or dripping from, vegetation canopy.

Transpiration: The process by which plants take water from the soil through their roots and lose it to the atmosphere via their leaves. 


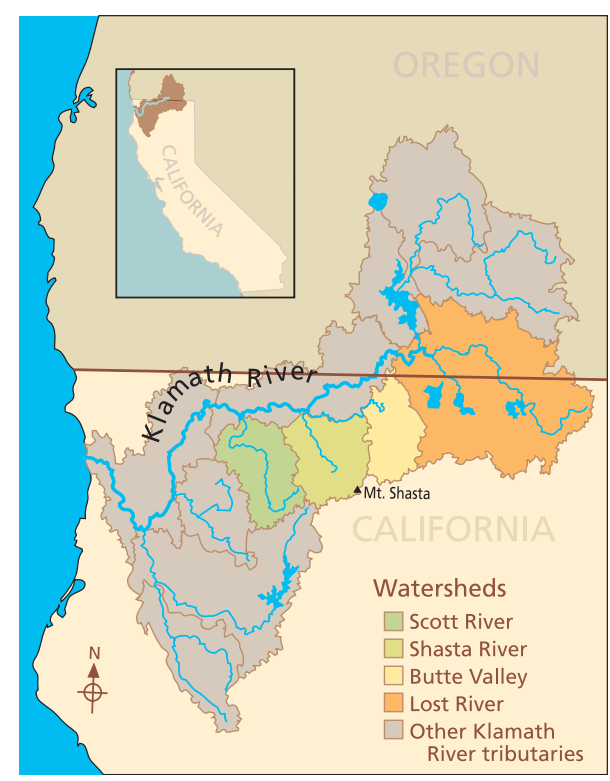

Fig. 1. The Klamath River Basin and the Scott River, Shasta River, Butte Valley and Lost River watersheds of Northern California and southern Oregon.

in reduced stream flows and groundwater recharge (Bosch and Hewlett 1982; Wilcox 2002).

Replacing a relatively high wateruse vegetation community such as juniper with a lower water-use community such as grasses is a common strategy to reduce plant-related water losses (Hibbert 1983). Reducing juniper densities can also provide other ecological and economic benefits, including increased forage production and quality for livestock and native wildlife, enhanced plant diversity, and reduced bare soil and erosion (Bates et al. 2000; Vaitkus and Eddleman 1987; Pierson et al. 2007).

The general expectation of ecological and hydrological benefits has led to hundreds of relatively small (1 to 1,000 acre) projects designed to convert juniper to sagebrush- or grass-dominated communities across the four arid watersheds of the Klamath River Basin located in California (figs. 1 and 2), as well as in the Oregon portion of the Basin. Most juniper control projects involve prescribed burning and cutting, and some are a combination of cutting and the removal of downed trees by prescribed burning.

We utilized existing research results to examine the possible hydrologi-

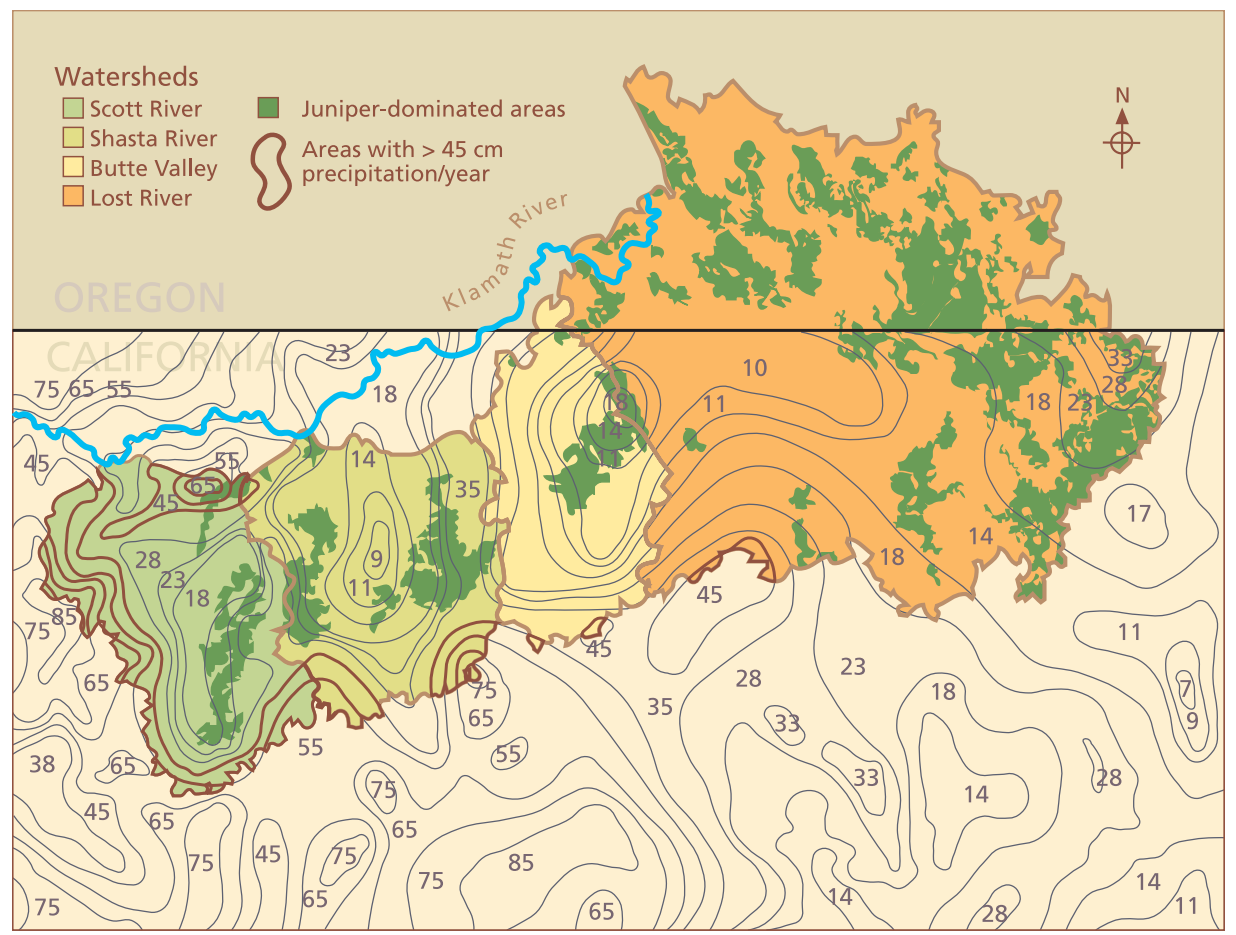

Fig. 2. Juniper-dominated areas and isohyetals (lines) showing total average annual precipitation (centimeters) within California for the Scott River, Shasta River, Butte Valley and southern Lost River watersheds. Bold isohyetals show watershed portions with more than $\mathbf{4 5}$ centimeters (17.7 inches) of annual precipitation. Only a small area in the northern Scott River watershed has both juniper dominance and greater than 45 centimeters (17.7 inches) annual precipitation.

cal consequences of increased juniper dominance in an arid to semiarid watershed, and the circumstances under which significant water-yield increases can be expected from juniper reduction projects such as those occurring in the Klamath River Basin. To assess the feasibility of augmenting Klamath River flows by removing juniper from these watersheds, we combined these research results with available rainfall and vegetation-dominance data for the major juniper-populated watersheds within the California portion of the Klamath River Basin.

\section{Impacts on stream flow}

Vegetation type is one factor that influences key hydrological processes that determine stream flow or water yield from a watershed. The water balance equation (Equation 1) accounts for the precipitation and subsequent water transport and storage, within as well as loss from, the watershed. Using this equation, Wilcox (2002) depicted the connection between vegetation and water budgets:

\section{$\mathrm{P}=\mathrm{ET}+\mathrm{R}+\mathrm{G}+\Delta \mathrm{S} \quad$ (Equation 1)}

The volume of precipitation $(\mathrm{P})$ falling on a watershed is equal to the sum of ET or water lost by evapotranspira- tion (including evaporation from surface water, soil surface or vegetation surfaces $[E]$ and transpiration by plants $[T]$ ), surface runoff as stream flow (R) or stored as groundwater $(\mathrm{G})$ and change in soil water $(\Delta S)$.

Eddleman et al. (1994) stated that, depending on the type, density and distribution of the vegetation that juniper invades, hydrological consequences may include increased vegetative interception, and a greater volume of water annually transpired and evaporated from juniper-dominated sites. While deep-rooted woody vegetation such as juniper tends to reduce water yields, a mix of shallow-rooted grasses and water-use-efficient shrubs tends to optimize water yields (Hibbert 1983). Conversion to less-water-demanding vegetation types affects site hydrology by: (1) decreasing leaf area and biomass, thereby reducing the amount of precipitation intercepted by vegetation canopy and lost due to evaporation (E), and (2) reducing the amount and depth from which water is withdrawn from the soil by transpiration (T) (Wilcox 2002). By reducing evapotranspiration, conversion to such low-water-use vegetation would potentially increase runoff, groundwater recharge and soil water storage. 


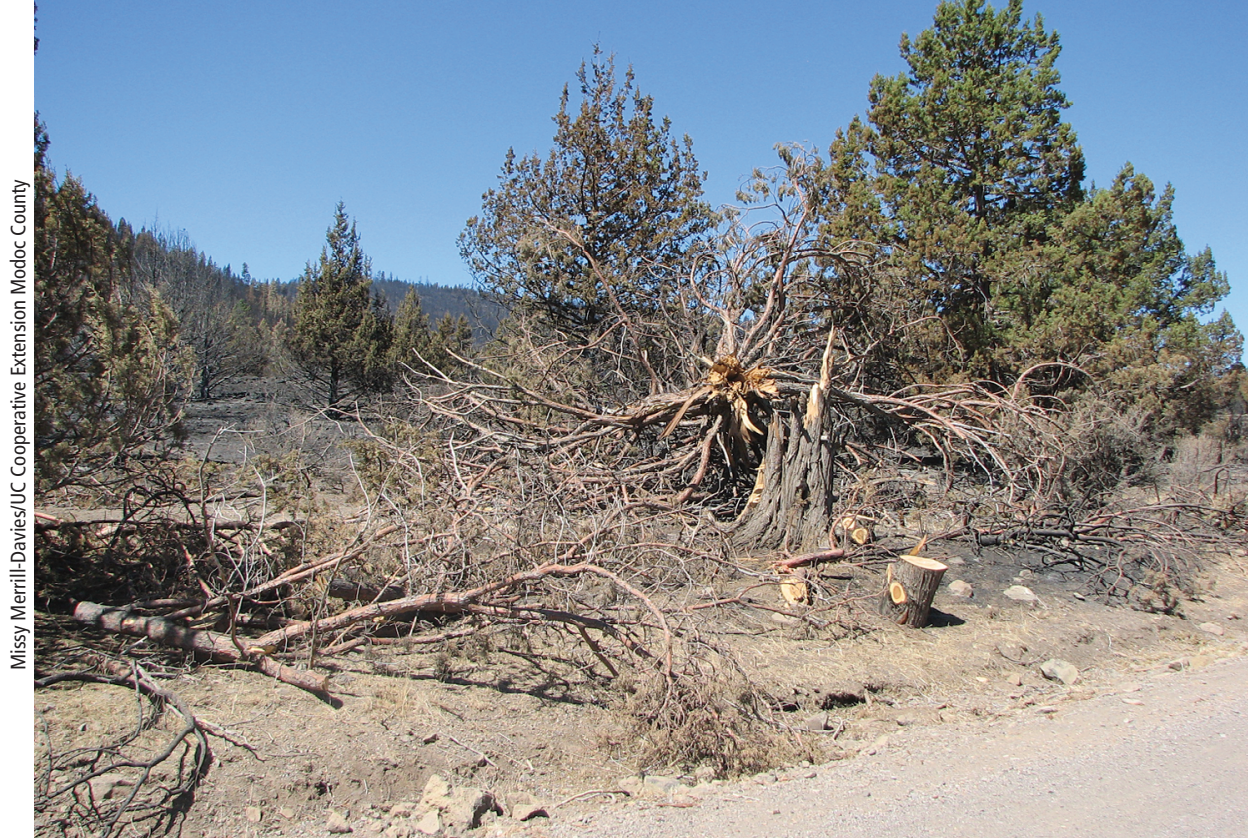

Numerous juniper removal projects have been implemented in the Klamath River Basin, including by cutting and prescribed burning.

However, this method of increasing water yield to arid watersheds in the eastern Klamath River Basin must be applied cautiously. Examining studies in arid and semiarid lands, Hibbert (1983) concluded that less than $1 \%$ of rangelands in the western United States are conducive to being successfully managed for increased water yield by vegetation conversion.

In arid watersheds, the potential to increase stream flow is complicated by high evaporation potential, high percentage of bare ground, and high direct evaporation of soil water (Bosch and Hewlett 1982; Hibbert 1983; Wilcox et al. 2002). Evaporation potential in arid watersheds can be so high that even when woody plant removal reduces transpiration, any soil water made available is then stored in the soil profile, directly evaporated from the soil profile, and/ or used by the plants that replace the woody vegetation. Under these circumstances, increased stream flow or groundwater recharge is not realized. Likewise, Huxman et al. (2005) reported that as woody vegetation was removed from an arid site, soil water evaporation was increased due to reduced soil surface shading. Huxman et al. (2005) also found that reduced tree canopies increased wind velocities at ground level, which enhanced transpiration by herbaceous plants and evaporation from bare soil.

\section{Impact of juniper expansion}

During the past century in the Northwest, including the upper
Klamath River Basin, the area occupied by western juniper has roughly doubled (Miller et al. 2005). Larsen (1993) postulated that the actual expansion rate in central Oregon was greater than 24,000 acres $(9,712$ hectares) per year. Miller and Rose (1995) reported that over $97 \%$ of western juniper woodlands in Oregon were dominated by trees less than 100 years old, indicating a massive recruitment of juniper during the past century of fire suppression. Although the range of juniper has shown considerable fluctuations in the past, recent expansion differs in that it is occurring under increasingly dry conditions (Miller and Wigand 1994). This expansion has been attributed to climate change, fire suppression and excessive grazing (Burkhardt and Tisdale 1976; Miller and Rose 1995). Once junipers are established at a site, their dominance appears to be essentially unaffected by competition from other plant species (Miller and Wigand 1994).

The shift to juniper dominance reduces the biomass and productivity of understory vegetation, as well as soil surface cover (Vaitkus and Eddleman 1987). This increased bare ground may reduce soil surface infiltration rates, which in turn would increase overland flow and reduce soil water storage. Pierson et al. (2007) found that even at lower rainfall rates, juniper-dominated hillslopes produced significantly more soil surface runoff and erosion than hillslopes with juniper removed in southeast Oregon.

\section{Juniper evapotranspiration}

Overall, evapotranspiration (ET) is the dominant water-budget component affected by juniper encroachment and juniper control projects. Evapotranspiration is composed of the following components: interception (I), evaporation (E) and transpiration (T) (Huxman et al. 2005; Wilcox 2002):

$$
\mathrm{ET}=\mathrm{I}+\mathrm{E}+\mathrm{T}(\text { Equation 2) }
$$

Interception and evaporation. Estimated interception by juniper trees varies considerably, and most published studies have focused on measuring interception by individual trees rather than at the watershed scale (table 1). Eddleman et al. (1994) reported that interception rates are largely dependent on factors such as vegetation size, distribution and density, as well as storm intensity, duration and precipitation type. Interception can be separated into four components: canopy interception, litter interception, throughfall (leaf drip) and stem flow. Vegetation on-site following juniper removal determines the long-term changes in interception. For instance, big sagebrush (Artemisia tridentata) is a common dominant shrub where juniper is expanding, and it exhibits similar interception rates to those

\begin{tabular}{llcc}
\multicolumn{2}{c}{ TABLE 1. Summary of results for juniper interception studies } \\
\hline \hline Research & Vegetation type & Canopy description & Interception \\
\hline Skau (1964) & Juniperus deppeana & Canopy cover 8-58\% & $\ldots \ldots \ldots$ \\
Young et al. (1984) & Juniperus occidentalis & 29.7 feet (9 meters) high; & $2-25$ \\
Larsen (1993) & Juniperus occidentalis & Canopy cover 9-43\% & 42 \\
Hull (1972) & Artemisia tridentata & Density was 2.2 plants/y & $9-15$ \\
$\begin{array}{l}\text { West and Gifford } \\
\text { (1976) }\end{array}$ & Artemisia tridentata & Not provided & 61 (snowfall) \\
\hline
\end{tabular}


TABLE 2. Estimated evapotranspiration (ET) for juniper

\begin{tabular}{llc}
\hline \hline Research & Vegetation type & ET* \\
\hline & & $\%$ \\
Gifford (1975) & Pinyon-juniper & $63-97$ \\
Lane and Barnes (1987) & Juniperus osteosperma and Juniperus deppeana & $80-100$ \\
Thurow and Hester (1997) & Juniperus pinchottii and Juniperus ashei & 100 \\
\hline * As \% of annual precipitation. & &
\end{tabular}

reported for western juniper (table 1). The determining factor is how the total vegetative surface area (juniper plus sagebrush) changes due to juniper encroachment and subsequent removal.

Total interception does not represent total evaporative loss, because some intercepted precipitation may reach the ground as throughfall or stem flow. While throughfall could be intercepted by litter below the tree canopy and then be lost to evaporation, stem flow will most often reach the soil profile. Young et al. (1984) and Larsen (1993) documented juniper stem flow to be less than $5 \%$ of total precipitation, but suggested it still may provide a significant advantage for juniper growth.

Important factors determining the amount of precipitation intercepted by juniper canopy during an individual storm event are storm intensity (precipitation rate), depth and duration. The canopy of each juniper has a certain interception capacity, and once this capacity is filled, any additional precipitation will reach the soil surface as throughfall or stem flow. Estimations of annual interception by juniper in a watershed must account for the number of storms that exceed the available interception capacity.

There is little published information on the effect of storm intensity, depth and duration on interception by juniper. However, these factors vary significantly across the four major tributary watersheds of the Klamath River Basin in California. For example, from the western edge of the Scott River watershed to the eastern edge of the Lost River watershed (fig. 2), the depth of precipitation ranges from 0.9 inches ( 2.3 centimeters) to 2.0 inches (5.1 centimeters) for a 6-hour storm event occurring on average every 2 years (NOAA 1973). For a 24 -hour storm event occurring on average every 2 years, the depth of precipitation ranges from 1.9 inches
( 4.8 centimeters) to 4.5 inches ( 11.4 centimeters) (NOAA 1973).

While interception and subsequent evaporative losses for western juniper litter on the soil surface are not known, interception by juniper litter may be considerable and possibly even greater than that by the canopy. Gifford (1970) reported that for closed canopies of pinyon pine (Pinus edulis) and Utah juniper (Juniperus osteosperma), 3.8 inches (9.6 centimeters) of precipitation penetrated only 9.8 inches ( 25 centimeters) into litter averaging 15 inches (38 centimeters) deep, never reaching the mineral soil surface. Conversely, for broken canopies at similar input volumes, water penetrated 59 inches (150 centimeters) into the soil profile. Thurow and Hester (1997) speculated that precipitation from most low-intensity, short-duration storms does not infiltrate into the soil profile due to canopy and litter interception.

Transpiration. Water losses from transpiration can be substantial (table 2) because western juniper is evergreen and possesses a root system that can readily exploit soil moisture throughout the soil profile (Miller et al. 1990; Young et al. 1984).

Increased transpiration affects water budgets by increasing the soil-water recharge demand (deficit) and reducing stream flow or groundwater recharge. Transpiration is driven by the moisture gradient (water potential) from moist soils near the roots to dry atmosphere at the leaf surface. Thus, transpiration rates are dependent upon soil moisture, relative humidity and air movement, which vary from site to site as well as across seasons and years. In southeastern Oregon juniper woodlands, Bates et al. (2000) illustrated a clear pattern of seasonal soil moisture depletion from April through September due to juniper transpiration, and the subsequent reduction in transpiration rates as soil moisture was depleted.
TABLE 3. Western juniper-dominated area within Klamath River Basin (California) watersheds

\begin{tabular}{lcc|}
\hline \hline Watershed & Total area & $\begin{array}{c}\text { Western juniper- } \\
\text { dominated }\end{array}$ \\
\hline Butte Valley & square miles & square miles (\%) \\
Scott River & 603 & $69(11)$ \\
Shasta River & 814 & $77(10)$ \\
Lost River & 795 & $140(18)$ \\
\hline
\end{tabular}

\section{Conversion and water yield}

Mixed findings. We found no quantitative studies assessing the conversion of western juniper for water yield augmentation. This represents an obvious gap in our knowledge of the feasibility of increasing water yields by removing western juniper in the Klamath River Basin. However, four studies have reported results on other juniper species in the western United States. These four juniper conversion projects had variable results, which could be attributed to differences in geographic location, precipitation regime, soil and geologic type, as well as in removal and postremoval activities (Hawkins 1987).

First, in a 12-year study of a southeastern Arizona watershed that was approximately 213 square miles (551 square kilometers), Collings and Myrick (1966) found no significant increase in annual water yield following juniper (J. osteosperma and J. deppeana) removal by cutting and prescribed burn. Annual precipitation at the study site was 20 inches ( 51 centimeters).

Second, in a 5-year study, Gifford (1975) examined storm runoff volumes from 1-acre (0.4-hectare) sites in southern Utah following juniper control by chaining (dragging a heavy chain between two bulldozers) with downed trees left on-site, compared to chaining with downed trees either left on-site or windrowed (piled into long rows). No information regarding mean annual precipitation was reported for either site. Gifford reported a 1.2- to 5-fold increase in runoff for the chained-withwindrowing treatment. No changes in runoff were observed where downed trees were left on-site after chaining, because the debris detained runoff and enhanced infiltration.

Third, Baker (1984) reported on a 14-year study of water yield following Utah juniper control with herbicide 
treatment on a 363-acre (147-hectare) subbasin in central Arizona. Average annual precipitation at the site was 18 inches (46.3 centimeters). Baker found an increase in annual stream flow of $157 \%$ in the first 2 years posttreatment, which was apparent but not statistically significant 8 years posttreatment.

Fourth, Dugas et al. (1998) documented a direct reduction in evapotranspiration by removing Ashe juniper (Juniperus ashei) cover on central Texas plots that were 0.6 square mile (1.5 square kilometers) with annual precipitation averaging 26.5 inches (67.3 centimeters). In this study, juniper removal caused an overall decrease in evapotranspiration by only 0.003 inch (0.07 millimeter) per day. A sustained reduction in evapotranspiration rates was limited due to the increased growth of herbaceous vegetation following juniper removal.

Rainfall is key. In an extensive review of 94 conversion experiments in various vegetation types, Bosch and Hewlett (1982) found no increases in water yield in areas averaging less than 17.7 inches (45 centimeters) of annual precipitation. Hibbert (1983) concurred with these findings, and reported that mean annual precipitation could be used as a principal determinant for the potential success of augmenting water yield. Wilcox (2002) further stressed that there is little prospect of increasing stream flows where mean annual precipitation is less than 19.7 inches (50 centimeters).

How much removal? The literature on how much juniper removal is required to increase water yields is limited. Bosch and Hewlett (1982) proposed that the amount of vegetative cover removed is proportional to changes in water yield and that, for many areas, removing less than $20 \%$ of the cover would not yield detectable changes in stream flows. In contrast, Hibbert (1983) reported that the relationship between percentage of vegetation removed and reduced transpiration is nonlinear, and that meaningful reductions in transpiration in arid environments are only achieved at high levels of removal. For instance, removing half of the deep-rooted vegetation may hypothetically result in only a $20 \%$ reduction in transpiration.

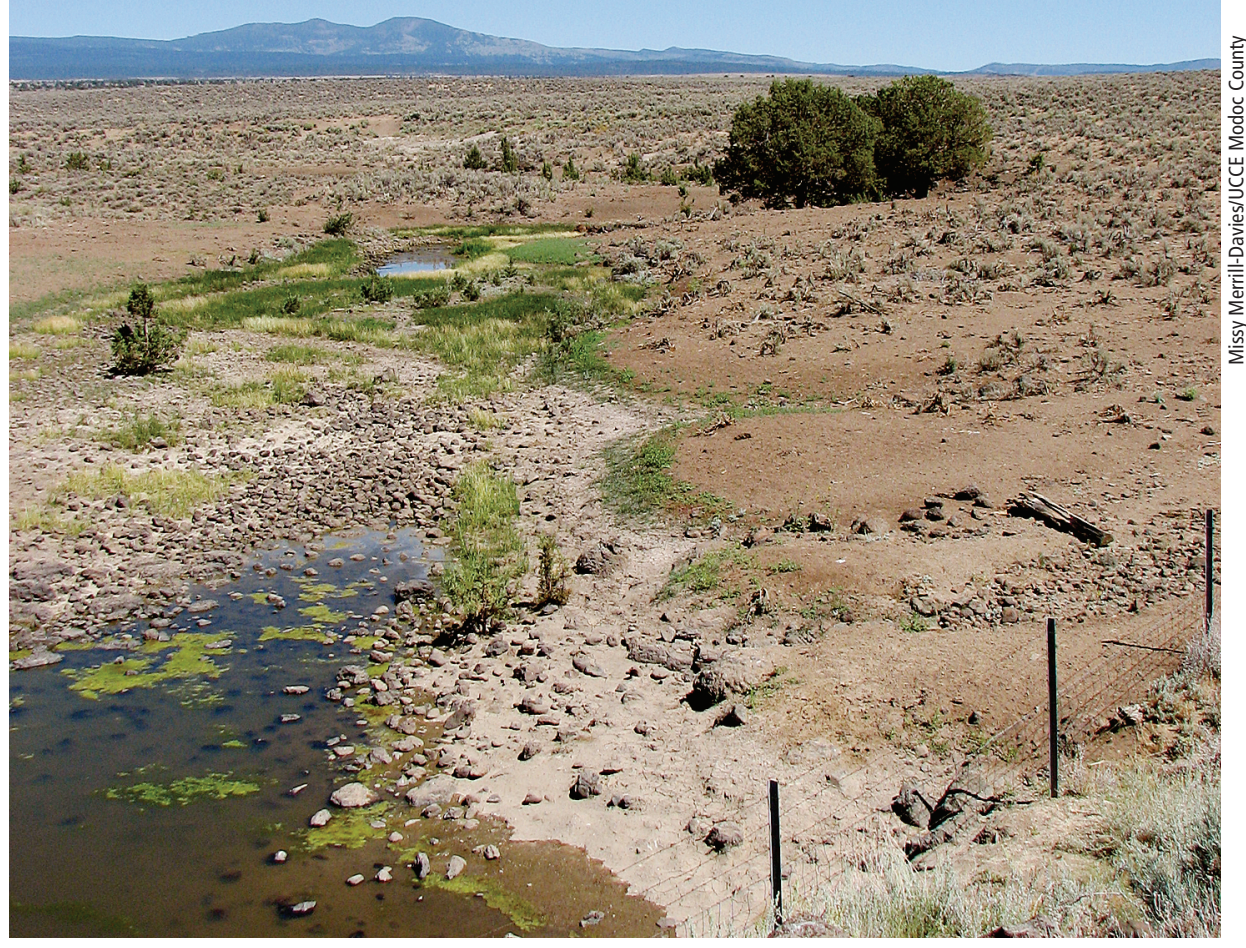

This review and analysis found that even the complete removal of juniper is not likely to significantly increase water yields in the California portion of the Klamath River Basin. Above, the Big Juniper drainage, between Alturas and Likely.

Hibbert also cautioned that tradeoffs exist between canopy removal and soil water evaporation because as greater amounts of canopy are removed, increases in solar radiation and wind energy may in turn increase the direct evaporation of soil moisture. It is critical that postremoval site evapotranspiration be maintained at low levels by converting residual vegetation to types that demand lower volumes of water. Hibbert recommended following juniper removal with the active seeding of grasses or other low-water-use vegetation. Dugas et al. (1998) suggested grazing treated sites to further limit the evapotranspiration demands from herbaceous plants.

\section{Conversion may not increase water}

Research published to date indicates that increasing water yields by juniper conversion is only feasible in portions of the Scott River, Shasta River, Butte Valley and southern Lost River watersheds where annual precipitation is greater than 17.7 inches (45 centimeters) (Bosch and Hewlett 1982; Hibbert 1983; Wilcox 2002). The primary mechanisms of water yield increase are reduced precipitation interception, evaporation and transpiration. In order to apply this information to the four Klamath River tributaries in
California that have significant areas dominated by juniper woodland, we sought to: (1) identify the areas dominated by juniper, (2) determine which areas have average annual precipitation above 17.7 inches and (3) determine the extent of overlap between the juniper-dominated areas and those receiving greater than 17.7 inches of annual precipitation.

We used a geographic information system (ArcGIS 9.0) to manage and overlay available spatial data layers of: (1) watershed boundary, (2) dominant vegetation and (3) annual precipitation for the portion of the Klamath River Basin defined by the boundaries of the Scott River, Shasta River, Butte Valley and southern Lost River watersheds within California. We did not consider portions of the Klamath River Basin within Oregon due to significant differences in the scale of available spatial vegetation data for the two states. The Gap Analysis of Mainland, Calif. (CSGA 1998) was utilized to delineate the areas of these watersheds dominated by juniper (minimum mapping unit greater than 247 acres [100 hectares]). Annual precipitation data for these watersheds was obtained from CSIL (2000), and lines connecting points of equal precipitation (isohyetal precipitation lines) were estimated for the four watersheds. 
We defined mapping units as dominated by western juniper when they had greater than $20 \%$ western juniper canopy (CSGA 1998) (fig. 2, table 3). Western juniper dominance was not observed in lower portions of the Klamath River Basin due to high precipitation in this area.

Based upon this analysis (fig. 2), we found that only 4,438 acres $(1,796$ hectares) within the 520,000-acre Scott River watershed are dominated by juniper and have greater than 17.7 inches of annual precipitation. There are no areas within the Shasta River, Butte Valley or southern Lost River watersheds that meet these requirements for expected water-yield increase by juniper removal. Only small areas in the extreme southern portion of these watersheds even have annual precipitation greater than 17.7 inches. Based upon this assessment and the assumptions stated, we can find no strong evidence that water yield from these watersheds can be substantially increased by even the complete removal of juniper.

However, it is important to remember the limitations of this analysis. First, there were substantial data and research gaps in our knowledge of how western juniper influences the hydrology and water budgets of watersheds in this region of Northern California. For example, field studies are needed at multiple spatial scales (from small catchments to entire watersheds) to examine how the water budget is affected by factors such as juniper coverage, age distribution and management; associate vegetation type; soil and geology; and precipitation amount, intensity and duration. In addition, the spatial scale used in this analysis was coarse, constrained by available vegetation data (> 247-acre minimum mapping unit) and in particular by precipitation data with a maximum reliable scale of 1:100,000 (CSIL 2000). Opportunities for small-scale water yield increases (such as increasing spring-wetland flow and extent in small catchments) cannot be adequately evaluated with the available data.

Our observations, and the experience of on-the-ground land managers, is that small increases in base flow and spring-associated stream flows have been realized after juniper conver- sion and wildfire in areas of the Lost River watershed. These increased flows are measured on the scale of tenths of a cubic foot per second of summer base flow in perennial streams, and increased duration of summer flow on intermittent streams. Although insignificant in the arena of increasing Klamath River flows, these flows are extremely critical for maintaining aquatic habitat and drinking water for wildlife as well as livestock. Given the importance and potential ecological and range management benefits of enhanced surface-water flows in this arid region, and the potential wildlife habitat and range quality improvements

\section{References}

Baker MB. 1984. Changes in stream flow in an herbicide-treated pinyon-juniper watershed in Arizona. Water Resources Res 20:1639-42.

Bates J, Miller RF, Svejcar T. 2000. Understory dynamics in cut and uncut western juniper woodlands J Range Manage 53:119-26.

Bosch JM, Hewlett JD. 1982. A review of catchment experiments to determine the effect of vegetation changes on water yield and evapotranspiration. J Hydrol 55:3-23.

Burkhardt JW, Tisdale EW. 1976. Causes of juniper invasion in southwestern Idaho. Ecology 57:472-84.

Collings MR, Myrick RM. 1966. Effects of juniper and pinyon eradication on stream flow from Corduroy Creek basin, Arizona. US Geol Surv Prof Pap 491-B, 12 p.

[CSGA] California State Gap Analysis. 1998. USGS Biogeography Lab-California gap analysis. Data ex-

tracted March 2005. www.biogeog.ucsb.edu/projects/ gap/gap_home.html.

[CSIL] California Spatial Information Library. 2000. Precipitation. Data extracted March 2005. http://casil. ucdavis.edu/casil/gis.ca.gov/teale/precipa.

Dugas WA, Hicks RA, Wright P. 1998. Effect of removal of Juniperus ashei on evapotranspiration and runoff in the Seco Creek watershed. Water Resources Res 34:1499-506.

Eddleman LE, Miller PM, Miller RF, Dysart PL. 1994 Western juniper woodlands of the Pacific Northwest Science Assessment. USDA Forest Service, Interior Columbia Basin Ecosystem Management Project. www.icbemp.gov/science/eddleman.pdf.

Gifford GF. 1970. Some water movement patterns over and through pinyon-juniper litter. Technical notes. J Range Manage 23:365-6.

Gifford GF. 1975. Approximate annual water budgets of two chained pinyon-juniper sites. J Range Manage 28:73-4.

Hawkins RH. 1987. Applied hydrology in the pinyon-juniper type. In: Proc Pinyon-Juniper Conference. Reno, NV. Ore Ag Exp Sta Tech Rep No 7763.

Hibbert RA. 1983. Water yield improvement potential by vegetation management on western rangelands. Water Res Bull 19:375-81.

Hull Jr AC. 1972. Rainfall and snowfall interception by big sagebrush. Abs Papers Proc Utah Acad Sci 49:64-5.

Huxman TE, Wilcox BP, Breshears DD, et al. 2005. Ecohydrological implications of woody plant encroachment. Ecology 86:308-19.

Lane LJ, Barnes FJ. 1987. Water balance calcula- that could result from juniper removal, field-based research should be conducted to improve our understanding of the role that juniper plays in local hydrology and the opportunities for managing juniper to augment local soil moisture and surface flows.

\section{T.J. Kuhn is Graduate Student Researcher, and} K.W. Tate is Rangeland Watershed Specialist, Department of Plant Sciences, UC Davis; D. Cao is GIS Specialist, SWCA Environmental Consultants, Sacramento; and M.R. George is Range and Pasture Specialist, Department of Plant Sciences, UC Davis.

tions in southwestern woodlands. In: Proc PinyonJuniper Conference. Reno, NV. Ore Ag Exp Sta Tech Rep No 7763.

Larsen RE. 1993. Interception and water holding capacity of western juniper. Ph.D. dissertation. Oregon State University, Corvallis, OR.

Levy S. 2003. Turbulence in the Klamath River basin. Bioscience 53:315-20.

Miller PM, Kramer S, Eddleman LE. 1990. Allocation patterns of carbon and minerals in juvenile and small-adult Juniperus occidentalis. Forest Sci 36:729-42.

Miller RF, Bates JD, Svejcar TJ, et al. 2005. Biology, Ecology, and Management of Western Juniper (Juniperus occidentalis). Ag Exp Sta Tech Bull No 152, Oregon State University.

Miller RF, Rose JA. 1995. Historic expansion of Juniperus occidentalis (western juniper) in southeastern Oregon. Great Basin Naturalist 55:37-45.

Miller RF, Wigand PE. 1994. Holocene changes in semiarid pinyon-juniper woodlands. Bioscience 44:465-74.

[NOAA] National Oceanic and Atmospheric Administration. 1973. Atlas 2 rainfall depthduration-frequency maps for the western United States. www.weather.gov/oh/hdsc/ currentpf.htm\#N2

Pierson FB, Bates JD, Svejcar TJ, Hardegree SP. 2007. Runoff and erosion after cutting western juniper. Range Ecol Manage 60:285-92.

Skau CM. 1964. Interception, throughfall and stem flow in Utah and alligator juniper cover types of northern Arizona. Forest Sci 10:283-7.

Thurow TL, Hester JW. 1997. How an increase or a reduction in juniper cover alters rangeland hydrology. In: Proc Juniper Symposium, Texas A\&M University, San Angelo, TX.

Vaitkus MR, Eddleman LE. 1987. Composition and productivity of a western juniper understory and its response to canopy removal. In: Proc PinyonJuniper Conference. Reno, NV. Ore Ag Exp Sta Tech Rep No 7763.

West NE, Gifford GF. 1976. Rainfall interception by cool desert shrubs. J Range Manage 29:171-3.

Wilcox BP. 2002. Shrub control and stream flow on rangelands: A process based viewpoint. J Range Manage 55:318-26.

Young JA, Evans RA, Easi DA. 1984. Stem flow on western juniper (Juniperus occidentalis) trees. Weed Sci 32:320-7. 